\title{
Keragaman genetik mimi (Carcinoscorpius rotundicauda dan Tachypleus gigas) di perairan Demak, Madura dan Balikpapan berdasarkan penanda Random Amplified Polymorphic DNA
}

\author{
Genetic diversity of horseshoe crabs (Carcinoscorpius rotundicauda and Tachypleus gigas) in \\ Demak, Madura and Balikpapan waters based on Random Amplified Polymorphic DNA marker

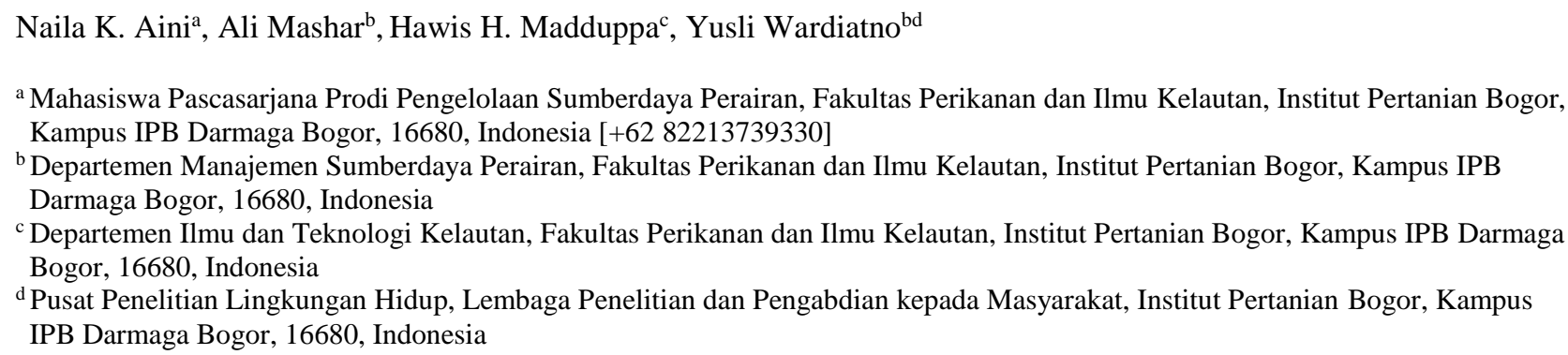

Article Info:

Received: 12 - 03 - 2020

Accepted: 31 - $03-2020$

Keywords:

Adaptation capability, heterozygosity, Limulidae, Xiphosura

Corresponding Author:

Yusli Wardiatno

Departemen Manajemen

Sumberdaya Perairan, Fakultas

Perikanan dan Ilmu Kelautan,

Institut Pertanian Bogor;

Tel. +628128608966

Email:

yusli@apps.ipb.ac.id

\begin{abstract}
Horseshoe crab is an exotic and protected marine organism in Indonesia and is considered as the living fossil animal in the world. IUCN conservation status of Carcinoscorpius rotundicauda and Tachypleus gigas is still Data Deficient, and in Indonesia research on genetic population is lacking, if any. This study aims to reveal genetic diversity of $\mathrm{C}$. rotundicauda and T. gigas populations in northern Java (Demak and Madura) and Balikpapan waters. This research was conducted by using molecular analysis with genetic markers Random Amplified Polymorphic DNA (RAPD). The primers used in this study were OPB 06, OPG 10, and OPX 03. The results showed that the highest polymorphism of $\mathrm{C}$. rotundicauda was found in Demak (74.6667\%) and heterozygosity was 0.2669. Furthermore, T. gigas had the highest polymorphism in Madura (74.3590\%) and heterozygosity was 0.25551 . Based on pairwise comparison tests, populations of $\mathrm{C}$. rotundicauda and T. gigas in Demak, Madura, and Balikpapan were significantly different $(p<0.05)$. The difference is believed due to the limitation movement of horseshoe crabs from and into the three locations, as well as the presence of natural geographic barrier. Thus, it can be concluded that horseshoe crabs in northern Java and Balikpapan waters has different genetic diversity. Genetically, horseshoe crab in northern Java or Balikpapan had relatively moderate diversity and low adaptation capability.
\end{abstract}

How to cite (CSE Style $8^{\text {th }}$ Edition):

Aini NK, Mashar A, Maduppa HH, Wardiatno Y. 2020. Keragaman genetik mimi (Carcinoscorpius rotundicauda dan Tachypleus gigas) di perairan Demak, Madura dan Balikpapan berdasarkan penanda Random Amplified Polymorphic DNA. JPSL 10(1): 124137. http://dx.doi.org/10.29244/jpsl.10.1.124-137. 


\section{PENDAHULUAN}

Mimi atau belangkas (horseshoe crab) merupakan salah satu hewan yang berasal dari famili Limulidae. Mimi adalah biota perairan yang eksotik dan merupakan salah satu living fossil animal yang ada di dunia (Eldredge dan Stanley, 1984). Hewan ini ditemukan sejak zaman Paleozolitikum periode Ordovician dan diduga nenek moyangnya berasal dari zaman Mesozolotikum. Hingga saat ini, di dunia terdapat empat jenis mimi. Carcinoscorpius rotundicauda (Latreille, 1802), Tachypleus gigas (Müller, 1785), dan Tachypleus tridentatus (Leach, 1819) ditemukan hidup di sekitar kawasan pantai Asia termasuk Indonesia dan biasa disebut dengan Asian horseshoe crab. Selanjutnya, Limulus polyphemus atau biasa dikenal sebagai Atlantic horseshoe crab hanya ditemukan di pantai Atlantik Amerika Utara (Walls et al., 2002).

Mimi adalah hewan yang dilindungi di Indonesia, namun penelitian terhadap hewan ini tidak sebanyak hewan yang dilindungi lainnya, misalnya seperti penyu (Ismane et al., 2018) atau gajah Sumatera (Febryano dan Rusita, 2018). Status konservasi setiap jenis mimi berbeda satu sama lain. Jenis C. rotundicauda dan $T$. gigas berstatus konservasi data deficient (World Conservation Monitoring Centre 1996a). Makna dari status tersebut adalah informasi yang ada saat ini belum memadai untuk menentukan resiko kepunahan dari kedua jenis mimi ini. T. tridentatus mempunyai status perlindungan endangered (EN) atau terancam punah (Laurie et al., 2019). Status konservasi T. tridentatus diperbarui pada bulan April 2019, status konservasi sebelumnya adalah data deficient (World Conservation Monitoring Centre, 1996b). Mimi jenis L. polyphemus mempunyai status IUCN lower risk / near threatened atau rentan (Smith et al., 2016).

Mimi mempunyai persebaran yang luas. Persebaran mimi terbagi menjadi dua wilayah yang besar yaitu di wilayah Atlantik Utara dan Asia. Persebaran mimi di Atlantik Utara terdapat di sepanjang pantai Atlantik dan Teluk Mexico dengan kelimpahan terbesar dapat ditemukan di antara Virginia dan New Jersey (Shuster, 1982). Persebaran mimi di wilayah perairan Asia mulai dari India hingga Jepang termasuk sekitar Indonesia dan Filipina (Walls et al., 2002). Persebaran mimi di perairan berkaitan dengan kondisi arus dan fase larva (planktonik) (Shanks, 2009). Mimi dewasa cenderung akan melakukan migrasi ke pantai untuk proses pemijahan dan meletakkan telur. Telur tersebut akan menetas setelah masa inkubasi selama kurang lebih dua hingga empat minggu (Sekiguchi et al., 1982). Setelah menetas menjadi larva, mimi akan bergerak menuju ke perairan terbuka untuk tumbuh dan berkembang. Larva mimi akan berenang bebas kurang lebih selama enam hari sebelum menetap (settle) di dasar perairan. Kondisi lingkungan perairan menentukan pergerakan larva mimi sebelum akhirnya menetap di dasar wilayah lokasi tertentu. Keterkaitan antara populasi di lokasi satu dengan lainnya dapat diketahui melalui penanda genetik.

Penanda genetik merupakan urutan DNA yang dapat diwariskan dari satu generasi ke generasi berikutnya. Urutan basa nukleotida yang beragam antar spesies dapat digunakan sebagai penanda spesifik yang memberikan pengetahuan mengenai hubungan filogenetik untuk mengatasi keraguan dalam sistematika. Penanda genetik Random Amplified Polymorphic DNA (RAPD) merupakan amplifikasi genom DNA berdasarkan teknik PCR (Williams et al., 1990). Analisis ini menggunakan primer tunggal dengan panjang urutan basa nukleotida sebanyak 10 basa. Analisis RAPD digunakan untuk melihat keragaman genetik berdasarkan tingkat polimorfisme. Ruas penempelan dengan perbedaan panjang fragmen DNA diasumsikan mengikuti pola pewarisan Mendel (Chauhan dan Rajiv, 2010). RAPD DNA fingerprint dapat memberikan penjelasan secara global jumlah urutan DNA dalam suatu populasi, walaupun terbatas oleh sifat anomin dari poliorfisme genetik yang diperoleh. Penanda RAPD mempunyai kelebihan tidak memerlukan informasi urutan basa nukleotida untuk melakukan pembacaan (Iyengar et al., 2000; Nebauer et al., 2000). Teknik ini lebih murah dan cepat untuk dilakukan. Kekurangan dari RAPD yaitu belum mampu membedakan antara lokus homozigot dan heterozigot sehingga memerlukan analisis urutan basa nukleotida dengan teknik yang beresolusi tinggi. Penelitian ini bertujuan untuk mengungkap keragaman genetik pada populasi mimi jenis $C$. rotundicauda dan T. gigas di perairan Demak, Madura, dan Balikpapan. 
Pemilihan lokasi tersebut berdasarkan pada dua pertimbangan. Pertama pesisir Balikpapan mewakili lokasi habitat mimi dengan kondisi ekosistem mangrove yang masih baik. Selain itu, mimi yang ditemukan di Balikpapan mempunyai ukuran yang lebih besar (Hery Seputro dari Dinas Pangan Pertanian dan Perikanan Kota Balikpapan, komunikasi pribadi 2019). Mangrove di Balikpapan terdapat di Kelurahan Teritip dengan luasan \pm 61.35 ha (Noor dan Helminuddin, 2009). Mimi yang ditemukan sekitar pesisir utara Jawa mempunyai ukuran yang lebih kecil jika dibandingkan dengan mimi yang berasal dari pesisir Balikpapan (Mashar et al., 2017). Kedua, sebagai pembanding dipilih lokasi pesisir utara Jawa khususnya Demak dan Madura sebagai ekosistem dengan kondisi sudah banyak terjadi kerusakan (Faturrohmah dan Majuki, 2017), tetapi masih terdapat ekosistem mangrove walaupun tidak sebaik di Balikpapan. Luasan mangrove di Demak (daerah Betahwalang) mencapai 37.41 ha (Faturrohmah, 2017) sedangkan di Madura (daerah Kalianget, Sumenep) adalah 39.4 ha (Muhsoni et al., 2011). Selain itu tekanan penangkapan terhadap sumberdaya mimi di kedua daerah tersebut cukup tinggi.

\section{METODE}

\section{Lokasi dan Waktu Penelitian}

Penelitian dilaksanakan pada bulan April hingga Desember 2019 di Laboratorium Biologi Molekuler, Departemen Manajemen Sumberdaya Perairan, Fakultas Perikanan dan Ilmu Kelautan, Institut Pertanian Bogor. Pengambilan sampel dilakukan di tiga lokasi yaitu Demak (daerah Betahwalang), Madura (daerah Kalianget, Sumenep), dan Balikpapan (Gambar 1).

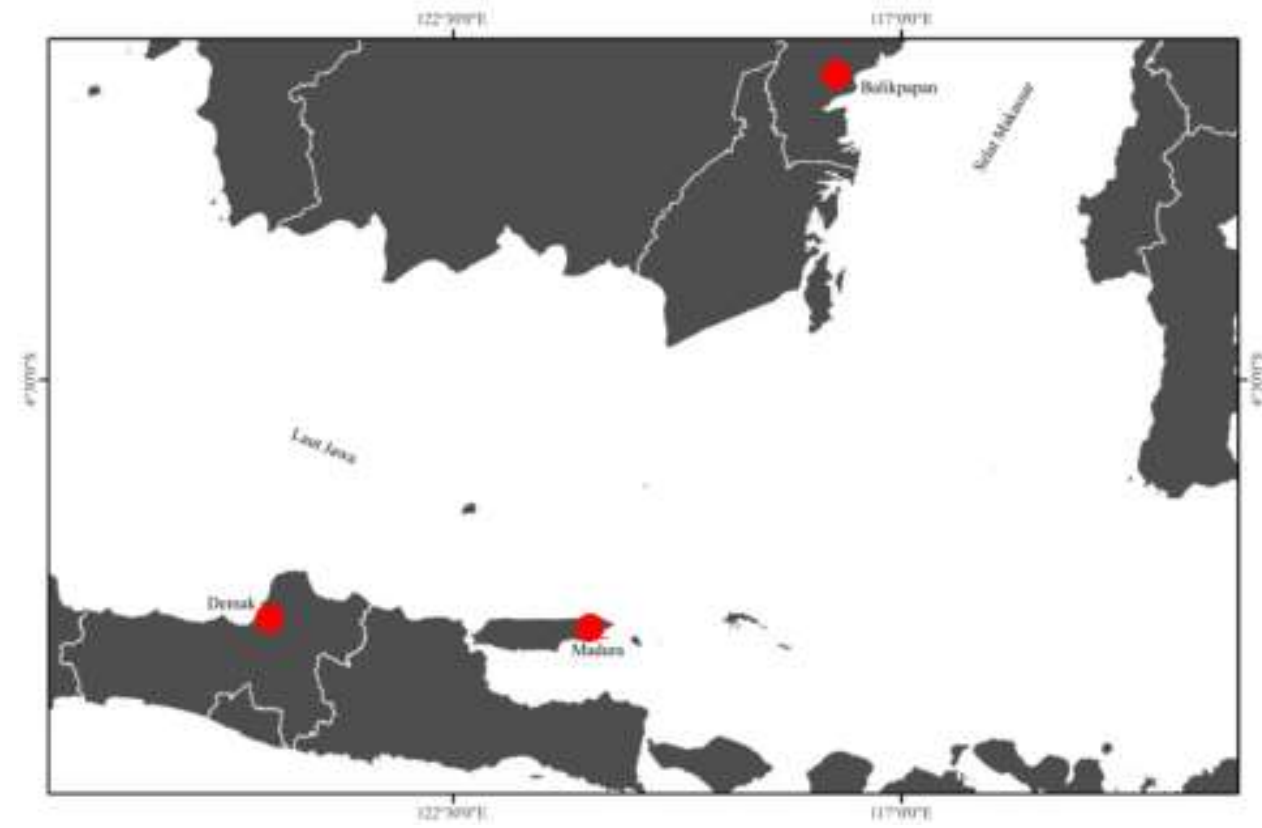

Gambar 1 Peta lokasi penelitian yang memperlihatkan titik pengambilan contoh kedua jenis mimi (bulatan merah), yakni $C$. rotundicauda dan $T$. gigas.

\section{Metode Pengumpulan Data}

Pengambilan contoh dilakukan dengan menggunakan teknik acak sederhana. Contoh mimi didapatkan dari jaring yang dijalankan oleh kapal nelayan atau diambil menggunakan tangan secara langsung. Contoh yang diambil adalah mimi jenis $C$. rotundicauda dan $T$. gigas. Dilakukan pengukuran mimi contoh yang didapatkan dalam kondisi hidup diambil darahnya masing-masing sebanyak $1 \mathrm{~mL}$ kemudian ditambahkan ke dalam tube berukuran $2 \mathrm{~mL}$ yang telah berisi alkohol absolute (100\%) sebanyak $1 \mathrm{~mL}$ (Dillon et al., 1996; Quicke et al., 1999). 


\section{Ekstraksi DNA}

Sampel darah yang berasal dari Demak, Madura, dan Balikpapan akan diisolasi dan diekstraksi, tetapi sebelumnya dilakukan pencucian terlebih terlebih dahulu untuk menghilangkan kandungan alkohol yang digunakan sebagai pengawetnya. Tahap pencucian dilakukan dengan menggunakan akuades. Sampel darah sebanyak 400-500 $\mu \mathrm{L}$ dipindahkan kedalam microtube $1.5 \mathrm{ml}$ kemudian disentrifius selama 1.5 menit dengan kecepatan $14000 \mathrm{rpm}$. Supernatan dihilangkan dan setiap tube diisi dengan akuades sebanyak $400 \mu \mathrm{L}$ dan disentrifius. Pencucian dilakukan sebanyak tiga kali. Setelah itu dilakukan isolasi dan diekstraksi untuk memperoleh total genom sesuai dengan arahan protokol GeneAID Kit.

\section{Amplifikasi PCR (Polymerase Chain Reaction) dengan metode RAPD}

Screening 13 jenis primer dilakukan sebagai tahap awal dalam analisis RAPD. Primer yang dipilih untuk analisis adalah primer yang mampu menghasilkan pitapolimorfik. Hasil pengujian tahap awal primer yang menghasilkan pita tersebut diantaranya adalah OPB 06, OPG 10, dan OPX 03. PCR dilakukan dengan menggunakan thermocyler gradient $(\mathrm{AB})$ dengan tujuan pengaturan suhu annealing dapat dilakukan sesuai dengan temperature melting (TM) masing-masing primer. Komponen bahan yang diginakan dalah PCR terdiri atas 12.5 $\mu \mathrm{L}$ Dream Taq Master Mix 2x (Thermo Scientific, USA), $1 \mu \mathrm{L}$ primer RAPD, $3 \mu \mathrm{L}$ DNA, dan ditambahkan free water sampai dengan total volume $25 \mu \mathrm{L}$. Tahapan PCR yang dilakukan diataranya denaturasi awal pada suhu $94^{\circ} \mathrm{C}$ selama dua menit, denaturasi $94^{\circ} \mathrm{C}$ selama satu menit, annealing dilakukan sesuai dengan TM masing-masing primer (OPB $0639.8^{\circ} \mathrm{C}$, OPG $1041.2^{\circ} \mathrm{C}$, OPX $0341.8^{\circ} \mathrm{C}$ ) selama satu menit, dan elongasi $72^{\circ} \mathrm{C}$ selama dua menit, dan post elongasi $72^{\circ} \mathrm{C}$ selama satu menit (modifikasi dari Williams et al., 1990).

\section{Elektroforesis dan Visualisasi}

Produk PCR kemudian dielekroforesis. Produk tersebut dimasukkan kedalam sumur pada gel agarose $1.5 \%$ sebanyak $6 \mu \mathrm{L}$ (sudah termasuk dye) (modifikasi dari Williams et al., 1990). Media yang digunakan adalah larutan 1x TBE (Tris Borate EDTA) (Lee dan Cowman 1994). Elektroforesis dilakukan bersama dengan marker 100 bp pada tegangan listrik sebesar 100 volt selama 60 menit menggunakan PowerPac Basic (BioRad). Visualisasi dilakukan dengan menggunakan bantuan sinar UV (Gel documentation -UV transiluminator Alphalmager).

\section{Metode Analisis Data}

Scoring kemunculan fragmen DNA dilakukan pada hasil elektroforesis yang telah diperoleh. Kemunculan fragmen tersebut akan bergantung pada berat molekul yang dihasilkan. Prediksi berat molekul produk amplifikasi dilakukan dengan menggunakan bantuan software AlphaView SA. Scoring dilakukan dengan cara memberikan nilai 1 untuk fragmen DNA yang mucul dan nilai 2 untuk fragmen DNA yang tidak muncul (mengubah menjadi data biner). Hasil scoring yang berupa data biner dianalisis dengan menggunakan software TFPGA (Tools for Population Genetic Analyses). Software tersebut digunakan untuk menentukan nilai derajat polimorfisme, heterozigositas, serta jarak genetik. Pembuatan dendrogram digunakan untuk melihat pengelompokan hirarki mimi yang berada di Demak, Madura, dan Balikpapan serta koefisien nilai $F_{S T}$ digunakan untuk melihat kemampuan migrasi individu. Kedua analisis tersebut dilakukan berdasarkan UPGMA (Unweighted Pair Group Arthimatic Average) (Miller, 1997). 


\section{HASIL DAN PEMBAHASAN}

\section{Hasil}

Hasil amplifikasi menggunakan primer OPB 06, OPX 03, dan OPG 10 pada 70 contoh mimi yang terdiri atas 30 individu C. rotundicauda dari ketiga lokasi penelitian masing-masing 10 individu (Demak, Madura, dan Balikpapan), 30 individu T. gigas juga dari lokasi yang sama (Gambar 2).

\section{Carcinoscorpius rotundicauda}

Berdasarkan hasil analisis diketahui bahwa setiap primer memiliki profil jumlah fragmen yang berbeda karena memiliki daerah penempelan yang berbeda-beda disetiap individu. Total jumlah lokus yang muncul dengan menggunakan tiga jenis primer (OPB 06, OPG 10, OPX 03) pada jenis $C$. rotundicauda di tiga lokasi adalah 75 lokus (Tabel 1). Jumlah lokus paling banyak berada pada primer OPG10 sebanyak 29 lokus, sedangkan jumlah paling sedikit pada primer OPB 06 sebanyak 19 lokus. Jumlah kisaran fragmen yang paling banyak ditemukan pada populasi $C$. rotundicauda di Balikpapan, sedangkan jumlah kisaran fragmen yang paling sedikit ditemukan di populasi Madura.

Hasil analisis ukuran fragmen pada jenis $C$. rotundicauda di masing-masing lokasi berbeda satu sama lain. Ukuran fragmen $C$. rotundicauda paling panjang diantara ketiga lokasi tersebut terdapat di Balikpapan dengan kisaran 200 hingga 2900 pb. Kisaran ukuran terpanjang C. rotundicauda di Balikpapan pada primer OPG 10 dan terpendek pada primer OPB 06. Kisaran ukuran fragmen C. rotundicauda di Madura paling rendah dibandingkan dengan lokasi lainnya yaitu pada kisaran ukuran 200 hingga 2400 pb. Pajang fragmen dengan ukuran terpanjang terdapat pada primer OPX 03 dan terpendek pada OPG 10. Ukuran fragmen C. rotundicauda di Demak berkisar antara 200 hingga 2500 pb, dengan ukuran terpanjang pada primer OPX 03 yaitu 400-2400 pb dan ukuran terpendek 200-1500 pb (Tabel 1).

Variasi keragaman genetik berdasarkan derajat polimorfisme dan heterozigositas C. rotundicauda di Demak, Madura, dan Balikpapan terdapat di Tabel 2. Berdasarkan hasil analisis, derajat polimorfisme tertinggi pada $C$. rotundicauda terdapat di Demak dengan nilai persentase sebesar $74.6667 \%$. Keragaman genetik terendah berdasarkan nilai derajat polimorfisme terdapat pada $C$. rotundicauda di Madura dengan nilai sebesar $58.6667 \%$. Selain derajat polimorfisme terdapat nilai heterozigositas yang dapat menggambarkan keragaman genetik. Nilai heterozigositas tertinggi pada $C$. rotundicauda terdapat di Demak sedangkan nilai heterozigositas terendah terdapat di Balikpapan yaitu 0.2669 dan 0.1885 . Sementara itu, nilai derajat polimorfisme antar populasi di ketiga lokasi tersebut adalah 76\% dengan nilai heterozigositas 0.2678.

Hasil uji $F_{S T}$ berpasangan ditampilkan pada Tabel 3. Berdasarkan hasil analisis menunjukkan bahwa antara ketiga populasi $C$. rotundicauda di Demak, Madura, dan Balikpapan pada ketiga spesies mempunyai karakter genotype yang berbeda secara signifikan satu sama lain $(p<0.05)$. Perbedaan terjauh terdapat di antara Madura dan Balikpapan sedangkan perbedaan terdekat derdapat diantara Demak dan Madura.

\section{Tachypleus gigas}

Berdasarkan hasil analisis RAPD diperoleh bahwa setiap jenis primer yang digunakan menampilkan jumlah dan ukuran fragmen yang disetiap individu. Jumlah lokus yang diperoleh dengan menggunakan primer OPB 06, OPG 10, OPX 03 pada jenis $T$. gigas di tiga lokasi adalah 78 lokus (Tabel 5). Jumlah lokus paling banyak berada pada primer OPG10 sebanyak 32 lokus, sedangkan jumlah paling sedikit pada primer OPB 06 sebanyak 19 lokus. Jumlah kisaran fragmen $T$. gigas di masing-masing lokasi hampir sama yaitu Demak sebanyak 2 hingga15, Madura 2 hingga16, dan Balikpapan 3 hingga14.

Jarak genetik yang diperoleh digambarkan dengan menggunakan dendogram (Gambar 3). Hasil tersebut menunjukkan bahwa jarak genetik $C$. rotundicauda di Demak dan Madura lebih dekat dibandingkan dengan Balikpapan yaitu (Tabel 4). Jarak genetik terjauh C. rotundicauda terdapat di antara Madura dan Balikpapan yaitu 0.3604 . 


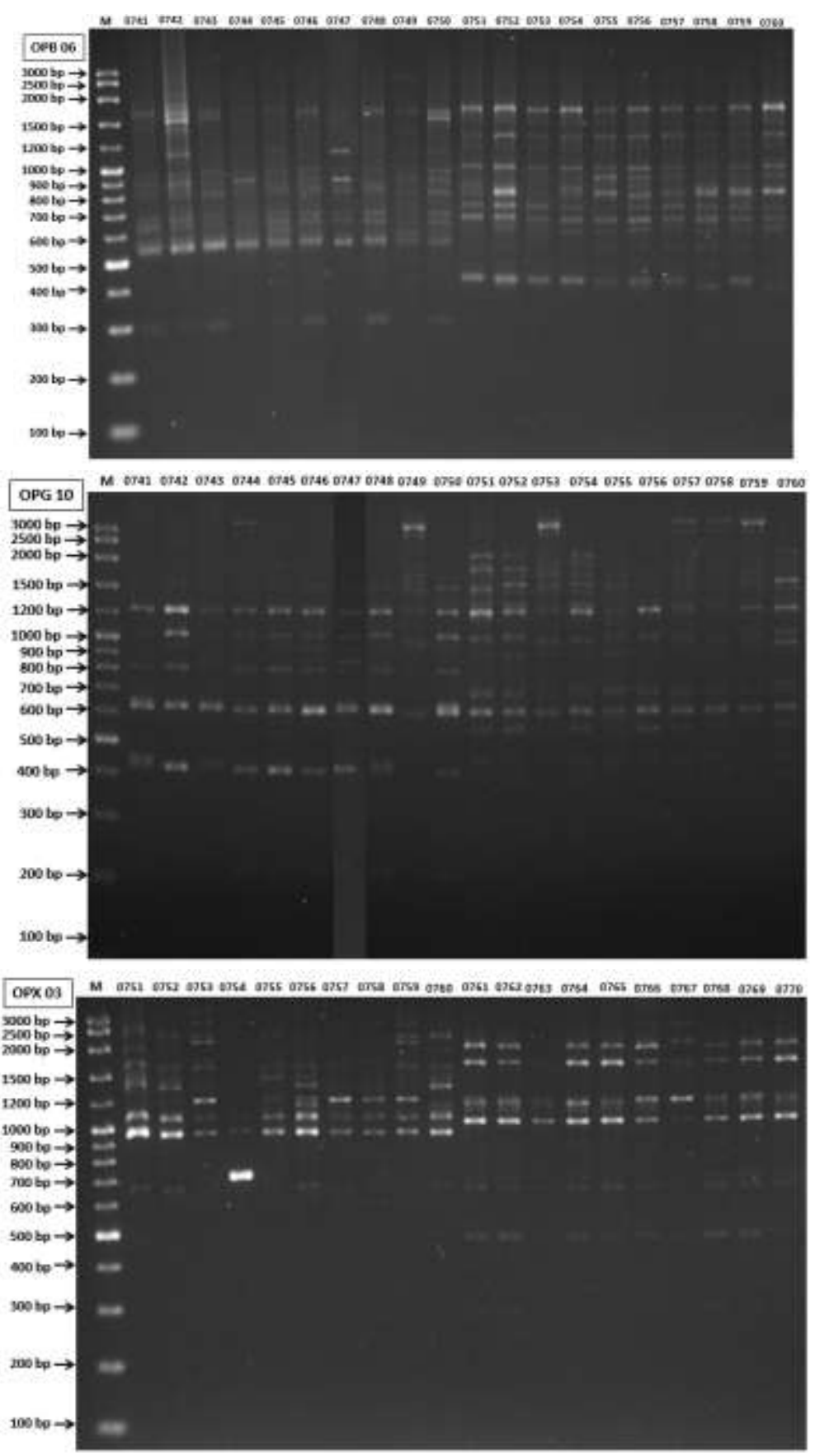

Gambar 2 Sebagian dari hasil amplifikasi dengan menggunakan primer OPB 06, OPX 03, dan OPG 10 pada C. rotundicauda dan $T$. gigas.

Tabel 1 Kisaran jumlah fragmen pada populasi C. rotundicauda yang diambil dari perairan utara Jawa (Demak dan Madura) dan Balikpapan.

\begin{tabular}{cccccccc}
\hline & \multicolumn{3}{c}{ Kisaran Jumlah Fragmen } & \multicolumn{2}{c}{ Kisaran Ukuran Fragmen (pb) } & $\begin{array}{c}\text { Jumlah } \\
\text { lokus per } \\
\text { primer }\end{array}$ \\
\cline { 2 - 7 } & Demak & Madura & Balikpapan & Demak & Madura & Balikpapan & \\
\hline OPB 06 & $0-12$ & $5-12$ & $7-12$ & $300-1500$ & $300-1800$ & $300-1700$ & 19 \\
OPG 10 & $0-16$ & $3-11$ & $6-11$ & $200-2500$ & $200-1500$ & $200-2900$ & 29 \\
OPX 03 & $0-14$ & $1-12$ & $5-12$ & $450-2400$ & $400-2400$ & $450-2800$ & 27 \\
\hline Total & $0-16$ & $3-12$ & $5-12$ & $200-2500$ & $200-2400$ & $200-2900$ & 75 \\
\hline
\end{tabular}


Tabel 2 Heterozigositas dan polimorfisme pada populasi C. rotundicauda yang diambil dari perairan utara Jawa (Demak dan Madura) dan Balikpapan.

\begin{tabular}{lcc}
\hline & Heterozigositas & Polimorfisme (\%) \\
\hline Demak & 0.2669 & 74.6667 \\
Madura & 0.1921 & 58.6667 \\
Balikpapan & 0.1885 & 64 \\
\hline Antar populasi & 0.2678 & 76 \\
\hline
\end{tabular}

Tabel 3 Nilai $F_{\text {ST }}$ populasi $C$. rotundicauda yang diambil dari perairan utara Jawa (Demak dan Madura) dan Balikpapan

\begin{tabular}{lccc}
\hline & Demak & Madura & Balikpapan \\
\hline Demak & - & & \\
Madura & 0.0004 & - & \\
Balikpapan & 0.0001 & 0.0000 & - \\
\hline
\end{tabular}

Tabel 4 Jarak genetik pada populasi $C$. rotundicauda yang diambil dari perairan utara Jawa (Demak dan Madura) dan Balikpapan

\begin{tabular}{lccc}
\hline & Demak & Madura & Balikpapan \\
\hline Demak & - & & \\
Madura & 0.2874 & - & \\
Balikpapan & 0.2963 & 0.3604 & - \\
\hline
\end{tabular}
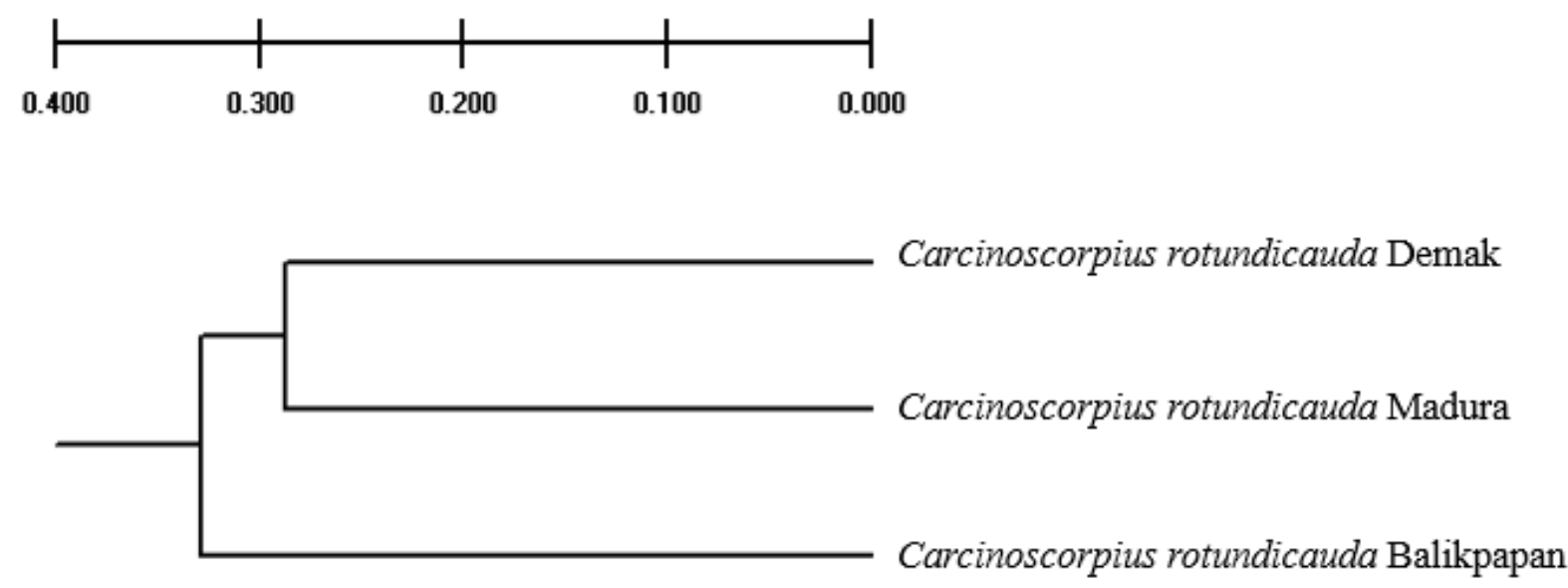

Gambar 3 Visualisasi jarak genetik pada populasi C. rotundicauda yang diambil dari perairan utara Jawa (Demak dan Madura) dan Balikpapan

Hasil analisis ukuran fragmen pada jenis $T$. gigas di setiap lokasi penelitian berbeda satu sama lain. Ukuran fragmen $T$. gigas di Balikpapan lebih panjang dibanding dengan lokasi lainnya yaitu kisaran 400 hingga 3000 pb. Kisaran ukuran terpanjang T. gigas di Balikpapan terdapat pada primer OPG 10 dan terpendek pada primer OPB 06. Berbeda halnya dengan $T$. gigas Demak yang mempunyai kisaran ukuran fragmen lebih rendah dibandingkan dengan lokasi lainnya yaitu 200 hingga $2500 \mathrm{pb}$. Populasi T. gigas di Demak ini mempunyai kirasan ukuran fragmen terpanjang terdapat pada primer OPX 03 dan terpendek pada OPG 10 (Tabel 5). 
Hasil analisis RAPD pada T. gigas di Demak, Madura, dan Balikpapan menunjukkan derajat polimorfisme dan nilai heterozigositas yang berbeda-beda (Tabel 6). Derajat polimorfisme tertinggi pada jenis T. gigas terdapat di Madura dengan nilai persentase sebesar $74.3590 \%$. Keragaman genetik terendahnya terdapat di Demak dengan nilai persentase sebesar $51.2821 \%$. Selain derajat polimorfisme terdapat nilai heterozigositas. Nilai heterozigositas tertinggi pada $T$. gigas terdapat di Madura sedangkan nilai heterozigositas terendah terdapat di Balikpapan yaitu 0.2551 dan 0.1864. Sementara itu, nilai derajat polimorfisme antar populasi di ketiga lokasi tersebut adalah $89.7436 \%$ dengan nilai heterozigositas 0.2938 .

Uji F $_{\text {ST }}$ berpasangan dilakukan untuk mengetahui kemampuan migrasi suatu individu. Berdasarkan hasil yang diperoleh pada Tabel 7 menunjukkan bahwa ketiga populasi T. gigas di Demak, Madura, dan Balikpapan berbeda secara signifikan $(p<0.05)$. hal tersebut mengartikan bahwa pola perpindahan $T$. gigas dari satu lokasi ke lokasi lainnya cenderung rendah. Selain itu, hasil analisis tersebut juga menunjukkan bahwa populasi $T$. gigas di ketiga lokasi mempunyai karakter genotype yang berbeda satu sama lain.

Berdasarkan hasil analisis, diperoleh nilai jarak genetik yang menunjukkan bahwa jarak genetik $T$. gigas di Demak dan Madura lebih dekat dibandingkan dengan T. gigas Balikpapan yaitu 0.3232 (Gambar 4). Jarak genetik terjauh T. gigas terdapat di antara Demak dan Balikpapan yaitu 0.4631 (Tabel 8).

Tabel 5 Kisaran jumlah fragmen pada populasi $T$. gigas yang diambil dari perairan utara Jawa (Demak dan Madura) dan Balikpapan

\begin{tabular}{cccccccc}
\hline & \multicolumn{3}{c}{ Kisaran Jumlah Fragmen } & \multicolumn{2}{c}{ Kisaran Ukuran Fragmen (pb) } & $\begin{array}{c}\text { Jumlah } \\
\text { lokus per } \\
\text { primer }\end{array}$ \\
\cline { 2 - 7 } & Demak & Madura & Balikpapan & Demak & Madura & Balikpapan & \\
\hline OPB 06 & $2-9$ & $2-11$ & $11-14$ & $400-1900$ & $400-1900$ & $400-1600$ & 19 \\
OPG 10 & $12-15$ & $6-16$ & $8-14$ & $200-2100$ & $300-2900$ & $400-2900$ & 32 \\
OPX 03 & $4-13$ & $7-13$ & $3-9$ & $300-2500$ & $300-2500$ & $650-3000$ & 27 \\
\hline Total & $2-15$ & $2-16$ & $3-14$ & $200-2500$ & $300-2900$ & $400-3000$ & 78 \\
\hline
\end{tabular}

Tabel 6 Heterozigositas dan polimorfisme pada populasi T. gigas yang diambil dari perairan utara Jawa (Demak dan Madura) dan Balikpapan

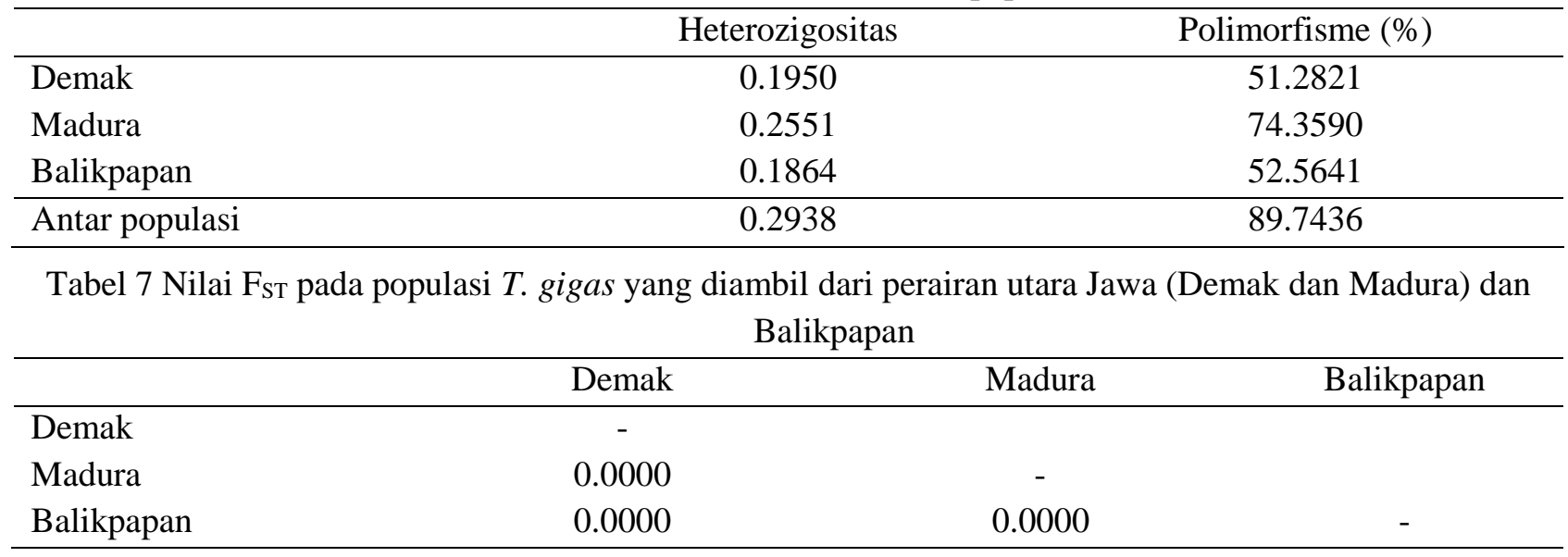

Tabel 8 Jarak genetik pada populasi T. gigas yang diambil dari perairan utara Jawa (Demak dan Madura) dan Balikpapan

\begin{tabular}{lccc}
\hline & Demak & Madura & Balikpapan \\
\hline Demak & - & & \\
Madura & 0.3232 & - & \\
Balikpapan & 0.4631 & 0.3847 & - \\
\hline
\end{tabular}




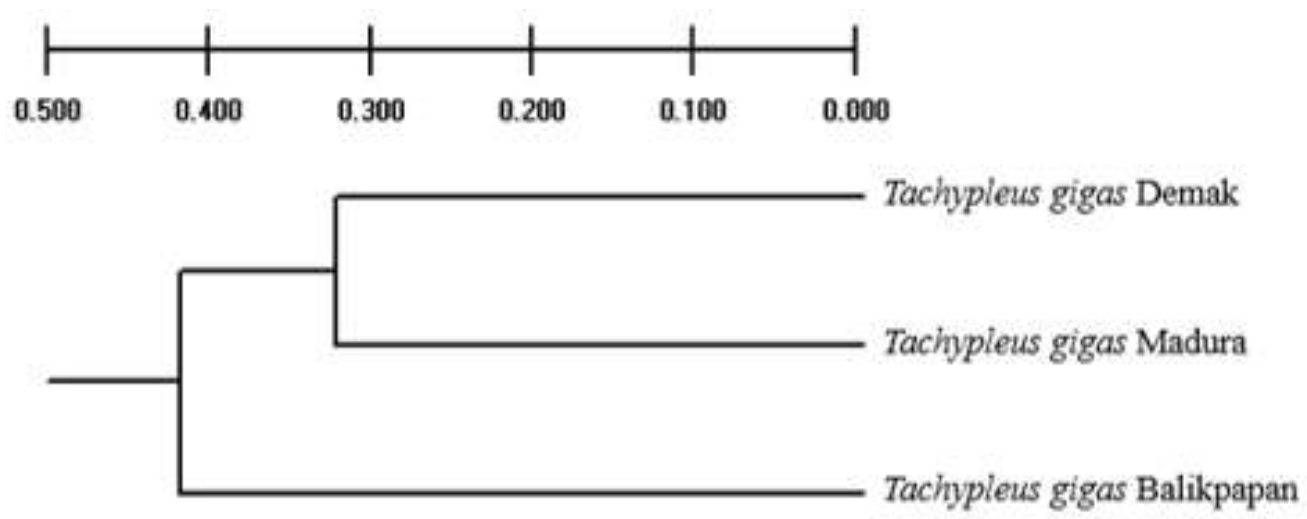

Gambar 4 Visualisasi jarak genetik pada populasi $T$. gigas yang diambil dari perairan utara Jawa (Demak dan Madura) dan Balikpapan

\section{Pembahasan}

Ukuran mimi yang ditemukan di Balikpapan cenderung lebih besar (Hery Seputro dari Dinas Pangan Pertanian dan Perikanan Kota Balikpapan, komunikasi pribadi 2019) diantaranya karena tekanan tangkapan mimi di Balikpapan lebih rendah. Hal tersebut dikarenakan mimi di Ballikpapan cenderung tidak dikonsumsi oleh masyarakat setempat. Kondisi mangrove di Balikpapan lebih luas dibandingkan dengan Demak (daerah Betahwalang) dan Madura (daerah Kalianget). Berbeda halnya dengan di Demak dan Madura, mimi di kedua daerah tersebut masih dikonsumsi oleh masyarakat khususnya betina yang bertelur (komunikasi pribadi 2019 dengan nelayan Betahwalang, Kabupaten Demak dan Kalianget, Kabupaten Sumenep, Madura). Ancaman keberadaan mimi menjadi serius dengan adanya budaya festival dugderan di Kendal, Jawa Tengah. Telur mimi di festival tersebut menjadi menu makanan yang sangat diminati, sehingga permintaan mimi betina bertelur menjadi meningkat. Tidak hanya di Indonesia, mimi betina bertelur juga menjadi salah satu menu makanan eksklusif di beberapa restoran mahal di Thailand dan Malaysia (Christianus dan Saad, 2007). Hal lain yang menjadi ancaman mimi adalah perlakuan nelayan terhadap mimi. Sebagian besar nelayan menyatakan bahwa mimi adalah hama yang bersifat merusak jaring nelayan apabila tertangkap, sehingga cenderung melakukan pelepasan paksa dari jaring. Selain itu, mimi juga dimanfaatkan secara komersil sebagai umpan penangkapan ikan sidat (Anguilla rostrata) (Kreamer dan Michels 2009), di Jambi (Kuala Tungkal) digunakan sebagai umpan ikan sembilang (Euristhmus microceps) (Rubiyanto 2012) dan beberapa juga di impor ke Amerika utara untuk digunakan sebagai umpan penangkapan (Smith et al. 2016).

Analisis kisaran ukuran dan jumlah fragmen yang menempel pada setiap induvidu berdasarkan primer masing-masing cenderung berbeda. Pemilihan primer dalam analisis RAPD berpengaruh karena setiap primer mempunyai situs penempelannya masing-masing. Hal tersebut mengakibatkan adanya perbedaan kemunculan pita polimorfik yang dihasilkan. Keberhasilan suatu primer dalam mengamplifikasi DNA template ditentukan oleh ada tidaknya kesamaan (homologi) antara sekuen nukleotida primer dan sekuen nukleotida DNA template. Hal lain yang juga dapat mempengaruhi perbedaan tersebut diantaranya suhu annealing, enzim Taq DNA polimerase, dan kualitas serta kuantitas DNA (Panner et al., 1999). Kontaminasi adanya senyawa lain saat ekstraksi juga dapat menurunkan kualitas pita dan konsentrasi DNA sehingga mempengaruhi kemunculan pita menjadi tidak jelas (Wedden et al., 1992). Sebelum melakukan analisis RAPD sebaiknya melakukan proses screening primer terlebih dahulu. Hal tersebut dilakukan dengan tujuan untuk memperoleh primer yang sesuai untuk dapat menghasilkan pita polimorfik. 
Keragaman genetik penelitian ini didasarkan derajat polimorfisme dan heterozigositas. Polimorfisme merupakan ukuran keragaman genetik berdasarkan proporsi lokus polimorf terhadap total lokus yang teridentifikasi, sedangkan heterozigositas adalah ukuran keragaman genetik berdasarkan proporsi jumlah individu heterozigot dalam populasi (Soewardi, 2007). Keragaman genetik C. rotundicauda berdasarkan derajat polimorfisme di Demak, Madura, dan Balikpapan masih tegolong sedang, namun dari ketiga lokasi tersebut $C$. rotundicauda di Demak mempunyai keragaman tertinggi. Hal tersebut juga didukung dengan nilai heterozigositas yang lebih tinggi dibandingkan dengan dua lokasi lainnya. Berbeda halnya dengan $T$. gigas keragaman tertinggi terdapat di Madura dengan nilai derajat polimorfisme dan heterozigositas masing-masing adalah $74.3590 \%$ dan 0.2551 . Nilai tersebut lebih rendah dibandingkan dengan polimorfisme $T$. gigas di Cherating, Malaysia yaitu 83.33\%, akan tetapi nilai tersebut juga lebih tinggi dibandingkan dengan T. gigas yang berasal dari Tanjung Dawai, Malaysia yaitu sebesar 44.44\% (Ismail et al., 2011).

Perbedaan nilai derajat polimorfisme terjadi karena perbedaan variasi genetik intrapopulasi dan pola diferensiasi populasi dalam penanda genetik seperti allozymes, DNA mitokondria, dan mikrosatelit (Selander et al., 1970; Saunders et al., 1986; King et al., 2005). Penelitian Primer RAPD pada dasarnya didesain untuk mendeteksi polimorfisme yang disebabkan oleh adanya mutasi poin (Smith, 2005). Kemunculan pita polimorfisme pada penelitian ini menunjukkan bahwa terdapat bentuk mutasi insersi dan delesi yang terjadi saat amplifikasi (Clark dan Lanigan, 1993). Hasil analisis menunjukkan bahwa nilai derajat polimorfime intrapopulasi dan interpopulasi pada spesies $C$. rotundicauda dan $T$. gigas masih tergolong sedang. Berdasarkan hasil yang diperoleh, nilai heterozigositas $C$. rotundicauda dan $T$. gigas intrapopulasi tergolong rendah dan cenderung homogen. Penurunan heterozigositas suatu populasi dapat menghilangkan keberadaan alel potensial, misal yang berkaitan dengan ketahanan terhadap penyakit, timbulnya abnormalitas, serta gangguan pertumbuhan (Slamat, 2009). Nilai heterozigositas dalam keragaman genetik menunjukkan tingkat potensi adaptasi terhadap lingkungan. Semakin rendah nilai heterozigositas maka semakin sedikit gen yang terlibat dalam menyumbangkan tingkat kebugaran suatu populasi yang artinya spesies tersebut mempunyai kemampuan adaptasi yang lemah (Tave, 1993). Secara umum, rendahnya keragaman genetik intrapopulasi akan memberikan efek terhadap rendahnya daya adaptasi suatu spesies dalam populasi untuk mempertahankan kelangsungan hidup jangka panjang (Schemske et al., 1994).

Uji perbandingan berpasangan $\left(\mathrm{F}_{\mathrm{ST}}\right)$ digunakan untuk melihat keterkaitan antara populasi. Hasil pengukuran keragaman antar populasi berdasarkan pada uji $\mathrm{F}_{\mathrm{ST}}$ menunjukkan bahwa populasi $C$. rotundicauda dan T. gigas di Demak, Madura, dan Balikpapan berbeda secara signifikan $(p<0.05)$. Hal tersebut mengindikasikan bahwa ketiga populasi $C$. rotundicauda dan $T$. gigas berasal dari stok dengan keragaman alel terfiksasi yang berbeda antar populasinya. Selain itu, hal tersebut juga mengindikasikan bahwa aliran gen (gene flow) yang terjadi antara ketiga populasi tersebut cenderung rendah. Perbedaan populasi tersebut diduga karena kemampuan mimi dalam melakukan perpindahan (movement) dari lokasi satu ke lokasi lainnya cenderung terbatas. King et al. (2005) menjelaskan bahwa secara genetik bahwa pergerakan mimi terbatas di beberapa bagian dari wilayah jelajahnya. Hal ini juga sesuai dengan hasil penelitian Moore dan Perrin (2007) terkait dengan penggunaan ruang dan pola pergerakan mimi (L. polyphemus) berdasarkan musim. Penelitian lain yang mendukung keterbatasan wilayah jelajah mimi pernah dilakukan di Taiwan untuk jenis T. tridentatus. Penelitian tersebut menjelaskan bahwa antar populasi terjadi aliran gen pada jarak $15 \mathrm{~km}$ dimana jarak tersebut dianggap sebagai jarak pendek antara dua populasi, aliran gen tidak ditemukan di antara dua populasi ketika jarak geografisnya melebihi $150 \mathrm{~km}$ (Yang et al., 2007). Jarak maksimum yang tercatat pada penelitian terkait pola pergerakan dan perpindahan L. polyphemus di teluk Great, New Hampshire (AS) adalah 9,2 km (Schaller et al., 2010). Studi populasi yang dilakukan di perairan Atlantik Utara mulai dari New York hingga teluk Delaware dan Chesapeake mencatat sebanyak 14 individu mimi yang melakukan pergerakan atau perpindahan pada kisaran jarak 104 - 265 km (Swan, 2005). Grogan (2004) berhasil mengungkap bahwa mimi mempunyai jarak perpindahan maksimum yang berbeda antara jantan dan betina. Mimi betina mampu menempuh jarak hingga $493.74 \mathrm{~km}$ sedangkan mimi jantan hanya mampu menempuh jarak maksimum $363.7 \mathrm{~km}$. Dengan demikian dapat dikatakan bahwa mimi betina mempunyai wilayah jelajah yang lebih luas dibandingkan dengan 
mimi jantan. Hal tersebut menjelaskan bahwa tidak cukup hanya jarak geografis yang menjadi pembatas antar populasi, akan tetapi terdapat faktor lain yang juga berperan penting salah satunya adalah adanya natural barriers (Pierce et al., 2000; Grogan, 2004).

Jarak genetik populasi mimi jenis $C$. rotundicauda dan $T$. gigas di ketiga lokasi penelitian terlihat bahwa hubungan kekerabatan mimi di Demak dan Madura lebih dekat dibandingkan dengan mimi yang berada di Balikpapan. Hal tersebut dapat terjadi karena mimi di Demak dan Madura masih berada dalam wilayah yang sama yaitu pantai utara Jawa. Berdasarkan siklus hidupnya, mimi dewasa cenderung berdiam di dasar dan melakukan perpindahan ke daerah pantai untuk melakukan proses reproduksi (Sekiguchi, 1988). Larva mimi jenis L. polyphemus cenderung akan bersifat planktonik selama periode waktu yang singkat sebelum akhirnya menerap didasar perairan (Shuster, 1982). Berbeda halnya dengan T. tridentatus, larva jenis ini setelah menetas akan mendiami daerah yang dekat dengan tempat menetasnya (natal beach) (Sekiguchi, 1988; Chen et al., 2004). Pada dasarnya mimi mempunyai wilayah jelajah yang terbatas (Pierce et al., 2000) terlebih untuk jenis C. rotundicauda yang habitatnya di mangrove, akan tetapi di daerah utara Jawa mimi menjadi salah satu komoditas makanan yang populer, sehingga terdapat kemungkinan adanya intervensi serta peran manusia (Chiu dan Morton, 1999).

\section{KESIMPULAN}

Mimi (C. rotundicauda dan T. gigas) di perairan Demak, Madura, dan Balikpapan berasal dari satu nenek moyang yang sama. Persentase nilai keragaman genetik cenderung sedang dan beresiko mengarah ke rendah. Kedua jenis spesies tersebut di masing-masing lokasi berpeluang membentuk spesies yang berbeda berdasarkan rendahnya tingkat adaptasi. Prediksi populasi mimi di Demak, Madura, dan Balikpapan kedepannya akan cenderung homogen secara genetik.

\section{UCAPAN TERIMA KASIH}

Penelitian ini didanai oleh Pusat Penelitian Oseanografi, Lembaga Ilmu Pengetahuan Indonesia (PPOLIPI) melalui Demand-Driven Research Fund (DDRF) No. B-5063/IPK.2/KS.02/III/2019 untuk YW dan IPB melalui skema PMDSU No. 6623/IT3.L1/PN/2019 ke YW (mengikuti kontrak antara Universitas IPB dan Kementerian Riset, Teknologi, dan Pendidikan Tinggi No. 261/SP2H/LT/DRPM/ 2019). Para penulis ingin mengucapkan terima kasih kepada mereka yang membantu dalam pengumpulan sampel dan pekerjaan laboratorium: Heri Seputro, Rani Nuraisah, Agus Alim Hakim, dan Ananingtyas Septia Darmarini.

\section{DAFTAR PUSTAKA}

Chauhan T, Rajiv K. 2010. Molecular markers and their applications in fisheries and aquaculture. Advances in Bioscience and Biotechnology. 1: 281-291.

Chen C-P, Yeh H-Y, Lin P-F. 2004. Conservation of horseshoe crabs in Kinmen, Taiwan: strategies and practices. Biodiversity and Conservation. 13: 1889-1904.

Chiu HMC, Morton B. 1999. The distribution of horseshoe crabs Tachypleus tridentatus and Carcinoscorpius rotundicauda in Hong Kong. Asian Marine Biology. 16:185-196.

Christianus A, Saad CR. 2007. Horseshoe crabs in Malaysia and the world. Fishery Mail. 16: 8-9.

Clark AG, Lanigan CMS. 1993. Prospects for estimating nucleotide divergence with RAPDs. Molecular and Biological Evolution. 10: 1096-1111.

Dillion N, Austin AD, Bartowsky E. 1996. Comparison of preservation techniques for DNA extraction from hymenopterous insects. Insect Molecular Biology. 5(1): 21-24.

Eldredge N, Stanley SM. 1984. Living Fossils. Berlin (BE): Springer. 
Faturrohmah S, Marjuki B. 2017. Identifikasi dinamika spasial sumberdaya mangrove di wilayah pesisir Kabupaten Demak Jawa Tengah. Majalah Geografi Indonesia. 31(1): 56-64.

Febryano IG, Rusita. 2018. Persepsi wisatawan dalam pengembangan wisata pendidikan berbasis konservasi gajah Sumatera (Elephas maximus sumatranus). Jurnal Pengelolaan Sumberdaya Alam dan Lingkungan. 8(3): 376-382.

Grogan WN. 2004. A mid-Atlantic study of the movement patterns and population distribution of the American horseshoe crab, L. Polyphemus. [master thesis]. Virginia (USA): Virginia Polytechnic Institute dan State University.

Ismail N, Taib M, Shamsuddin AA, Shazani S. 2011. Genetic variability of wild horseshoe crab, Tachypleus gigas (MÜller) in Tanjung Dawai, Kedah and Cherating, Pahang, Peninsular Malaysia. European Journal of Scientific Research. 60 (4): 592-601.

Ismane MA, Kusmana C, Gunawan A, Affandi R, Suwardi S. 2018. Keberlanjutan pengelolaan kawasan konservasi penyu di pantai Pangumbahan, Sukabumi, Jawa Barat. Jurnal Pengelolaan Sumberdaya Alam dan Lingkungan. 8(1): 36-43.

Iyengar A, Piyapattanakorn S, Stone DM, Heipel DA, Howell BR, Baynes SM, Maclean N. 2000. Identification of microsatellite repeats in turbot (Scophthalmus maximus) and dover sole (Solea solea) using RAPDbased technique: characterization of microsatellite markers in dover sole. Marine Biotechnology. 2: 49-56.

King TL, Eackles MS, Spidle AP, Brockmann HJ. 2005. Regional differentiation and sex-biased dispersal among populations of the horseshoe crab Limulus polyphemus. Transactions of the American Fisheries Society. 134: 441-465.

Kreamer G, Michels S. 2009. History of horseshoe crab harvest on Delaware Bay. Di dalam: Biology and conservation of horseshoe crabs. Tanacredi JT, Botton ML, Smith DR, editor. New York (NY): Springer. hlm 299-313.

Laurie K, Chen CP, Cheung SG, Do V, Hsieh H, John A., Mohamad F, Seino S, Nishida S, Shin P, Yang M. Tachypleus tridentatus (errata version published in 2019). The IUCN Red List of Threatened Species 2019 [Internet]. 2019 [cited 2020 Jan 18]. Available from: https://www.iucnredlist.org/species/21309/149768986.

Leary RF, Allendrof FW, Knudsen KL. 1985. Development instability and high meristic counts in interspecific hybrid of salmonid fishes. Evolution. 39: 318-326.

Mashar A, Butet NA, Juliandi B, Qonita Y, AA Hakim, Wardiatno Y. 2017. Biodiversity and distribution of horseshoe crabs in northern coast of Java and southern coast of Madura. IOP Conference Series: Earth and Environmental Science. 54: 012076.

Meilana L, Wardiatno Y, Butet NA, Krisanti M. 2016. Karakter morfologi dan identifikasi molekuler dengan marka gen CO1 pada mimi (Tachypleus gigas) di Perairan Utara Jawa. Ilmu dan Teknologi Kelautan Tropis. 8: 145-158.

Miller MP. 1997. Tools for population genetic analysis (TFPGA) 1.3: A windows program for the analysis of allozyme and molecular population genetic data. Software didistribusikan oleh penulis. Tersedia di: http://www.marksgeneticsoftware.net/.

Moore S, Perrin S. 2007. Seasonal Movement and Resource-Use Patterns of Resident Horseshoe Crab (Limulus polyphemus) Populations in a Maine, USA Estuary. Estuaries and Coasts. 30 (6): 1016-1026.

Muhsoni FF, Syarief M, Effendi M. 2011. Inventarisasi data potensi sumberdaya wilayah pesisir Kabupaten Sumenep. Jurnal Kelautan. 4(1): 96 - 201.

Nebauer SG, del Castillo-Agudo L, Segura J. 2000. An assesment of genetic relationships within the genus Digitalis based on PCR-generated RAPD markers. Theoretical and Applied Genetics. 100:1209-1216.

Noor P, Helminuddin. 2009. Valuasi ekonomi pemanfaatan hutan mangrove di kelurahan Teritip kota Balikpapan. Jurnal Kehutanan Tropika Humida. 2 (1): 69-80. 
Penner GA, Bush A, Wise R, Kim W, Domier L, Kasha K, Laroche A, Scoles G, Molnar SJ, fedak G. 1993. Reproducibility of random amplified polymorphic DNA (RAPD) analysis among laboratories. PCR Methods Applications. 2(4): 341-345. doi:10.1101/gr.2.4.341.

Pierce JC, Tan G, Gaffney PM. 2000. Delaware bay and Chesapeake bay populations of the horseshoe crab Limulus polyphemus are genetically distinct. Estuaries. 23: 690-698.

Quicke DLJ, Belshaw R, Lopez-Vaamonde C. 1999. Preservation of hymenopteran specimens for subsequent molecular and morphological study. Zoologica Scripta. 28(1-2): 261-267.

Rubiyanto E. 2012. Studi Populasi Mimi (Xiphosura) di Perairan Kuala Tungkal, Kabupaten Tanjung Jabung Barat, Jambi [tesis]. Depok (ID): Universitas Indonesia.

Saunders NC, Kessler LG, Avise JC. 1986. Genetic variation and geographic differentiation in mitochondrial DNA of the horseshoe crab, Limulus polyphemus. Genetics. 112(3): 613-627.Schaller YS, Chabot CC, Watson III WH. 2010. Seasonal movements of American horseshoe crabs L. polyphemus in the Great Bay Estuary, New Hampshire USA. Current Zoology. 56(5): 587-598.

Schaller YS, Chabot CC, Watson III WH. 2010. Seasonal movements of American horseshoe crabs $L$. polyphemus in the Great Bay Estuary, New Hampshire USA. Current Zoology. 56(5): 587-598.

Schemske DW, Husband BC, Ruckelshaus MH, Goodwillie C, Parker IM, Bishop JG. 1994. Evaluating approaches to the conservation of rare and endangered plants. Ecology. 75: 584-606

Sekiguchi K, Yamamichi Y, Costlow JD. 1982. Horseshoe crab development studies I. Normal embryonic development of Limulus polyphemus compared with Tachypleus tridentatus. Di dalam: Boneventura J, Bonaventura C, Tesh S, editor. Physiology and Biology of Horseshoe Crabs: Studies on Normal and Environmentally Stressed Animals. New York (NY): Alan R. Liss, Inc. hlm 53-73.

Sekiguchi K. 1988. Biology of Horseshoe Crabs. Tokyo (JPN): Science House.

Selander RK, Yang SY, Lewontin RC, Johnson WE. 1970. Genetic variation in the horseshoe crab (Limulus polyphemus), a phylogenetic "relic". Evolution. 24: 402-414.

Shanks AL. 2009. Pelagic larval duration and dispersal distance revisited. Biological Bulletin. 16: 373-385.

Shuster CN Jr. 1982. A pictorial review of the natural history and ecology of the horseshoe crab, Limulus polyphemus, with reference to other limulidae. pp. 1-52. In: Physiology and Biology of Horseshoe Crabs: Studies on Normal and Environmentally Stressed Animals. (Bonaventura JC. Bonaventura, dan S. Tesh, Eds. New York (NY): Alan R Liss, Inc.

Slamat. 2009. Keanekaragaman genetik ikan betok (Anabas testudineus Bloch) pada ekosistem perairan rawa di Provinsi Kalimantan Selatan [master tesis]. Bogor (ID): Institut Pertanian Bogor.

Smith DR, Beekey MA, Brockmann HJ, King TL, Millard MJ, Zaldívar-Rae JA. 2016. Limulus polyphemus. The IUCN Red List of Threatened Species 2016. e.T11987A80159830. Available online at: http://www. iucnredlist.org/details/11987/0.

Smith JP. 2005. Random amplified polymorphic DNA (RAPD). Stock Identification Methods. 5(18): 371-388.

Soewardi K. 2007. Pengelolaan Keragaman Genetik Sumberdaya Perikanan dan Kelautan. Bogor (ID): Institut Pertanian Bogor.

Swan BL. 2005. Migrations of adult horseshoe crabs, Limulus polyphemus, in the Middle Atlantic Bight: a 17year tagging study. Estuaries. 29(1): 28-40.

Tave D. 1993. Genetic for fish hatchery managers. Netherland (EU): Kluwer Academic Publishers.

Walls EA, Berkson J, Smith SA. 2002. The horseshoe crab, Limulus polyphemus: 200 million years of existence, 100 years of study. Reviews in Fisheries Science. 10(1): 39-73.

Weeden NF, Timmerman GM, Hemmat M, Kneen BE, Lodhi M.A. 1992. Inheritance and reliability of RAPD markers. In: Applications of RAPD Technology to Plant Breeding. Joint Plant Breeding Symposia Series, November 1, 1992, Minneapolis, MN. Crop Science Society of America, Madison, WI.

Williams JG, Kubelik AR, Lival KJ, Rafalski JA, Tingey SV. 1990. DNA polymorphisms amplified by arbitrary primers are useful as genetic markers. Nucleic Acids Research. 18: 6531-5. 
World Conservation Monitoring Centre. 1996b. Tachypleus Tridentatus, The IUCN Red List of Threatened Species [Internet]: [diunduh 28 Maret 2020] e. T21309A9267047. Tersedia pada: https://doi.org/ 10.2305/ IUCN.UK.1996.RLTS.T21309A9267047.en

World Conservation Monitoring Centre. 1996a. Tachypleus gigas. The IUCN Red List of Threatened Species [Internet]. [diunduh 18 Januari 2020]. Tersedia pada: https://www.iucnredlist.org/species/21308/ 9266907.

Yang MC, Chen CA, Hsieh HL, Chen CP. 2007. Population Subdivision of the tri-spine horseshoe crab, Tachypleus tridentatus in Taiwan Strait. Zoological Science. 24: 219-224.Yang MC, Chen CA, Hsieh HL, Chen CP. 2007. Population Subdivision of the tri-spine horseshoe crab, Tachypleus tridentatus in Taiwan Strait. Zoological Science. 24: 219-224. 